\title{
Phytotherapy Research
}

\section{A Multifactorial Comparison of Ternary Combinations of Essential Oils in Topical Preparations to Current Antibiotic Prescription Therapies for the Control of Acne Vulgaris- Associated Bacteria.}

\begin{tabular}{|c|c|}
\hline Journal: & Phytotherapy Research \\
\hline Manuscript ID & PTR-16-1256 \\
\hline Wiley - Manuscript type: & Research Article \\
\hline Date Submitted by the Author: & 05-Oct-2016 \\
\hline Complete List of Authors: & $\begin{array}{l}\text { Owen, Lucy; De Montfort University, School of Pharmacy } \\
\text { Grootveld, Martin; De Montfort University, School of Pharmacy } \\
\text { Arroo, Randolph; De Montfort University, Pharmacy } \\
\text { Ruiz-Rodado, Victor; De Montfort University, School of Pharmacy } \\
\text { Price, Penny; Penny Price Aromatherapy } \\
\text { Laird, Katie; De Montfort University, School of Pharmacy }\end{array}$ \\
\hline Keyword: & $\begin{array}{l}\text { Essential oils, Acne vulgaris, }<i>\text { Propionibacterium acnes }</ i>\text {, } \\
<i>\text { Staphylococcus epidermidis }</ i>\text {, antimicrobial synergy }\end{array}$ \\
\hline
\end{tabular}

\section{SCHOLARONE $^{\text {m }}$}

Manuscripts 
A Multifactorial Comparison of Ternary Combinations of Essential Oils in Topical Preparations to Current Antibiotic Prescription Therapies for the Control of Acne VulgarisAssociated Bacteria.

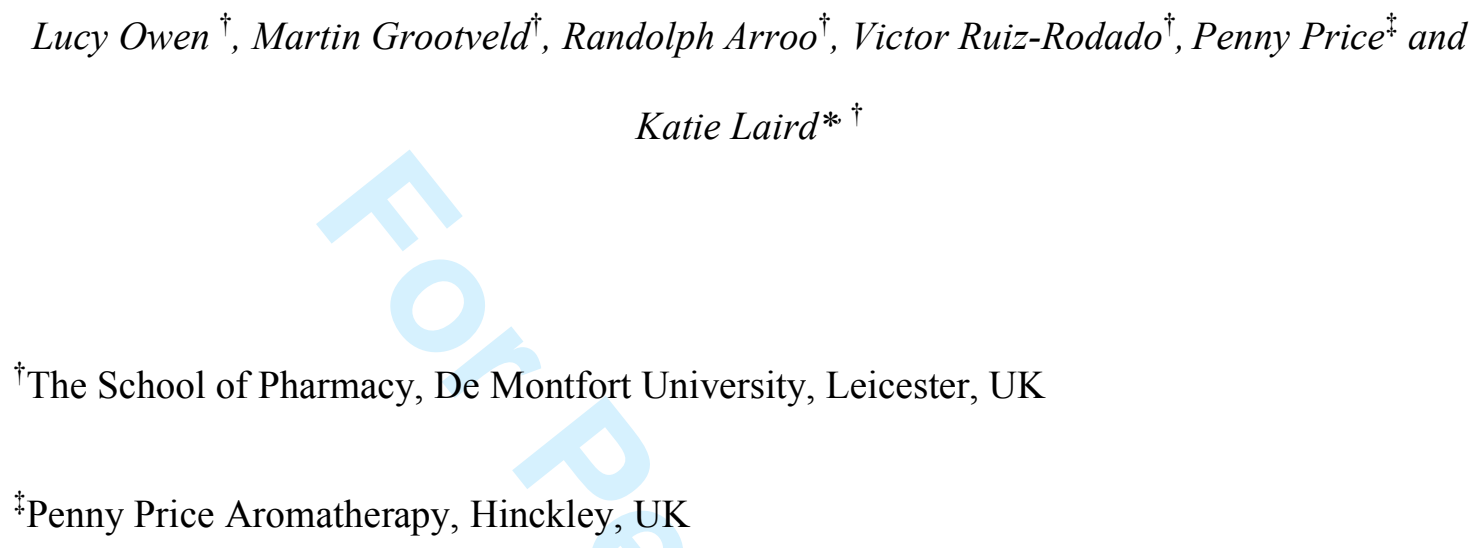

${ }^{\dagger}$ The School of Pharmacy, De Montfort University, Leicester, UK

${ }^{\ddagger}$ Penny Price Aromatherapy, Hinckley, UK

*Corresponding Author: Katie Laird, The School of Pharmacy, De Montfort University, The Gateway, Leicester, LE1 9BH, UK. Email: klaird@dmu.ac.uk. Tel: +441162078106.

Key words: Essential oils; acne vulgaris; Propionibacterium acnes; Staphylococcus epidermidis; antimicrobial synergy. 


\begin{abstract}
Acne vulgaris, a chronic condition associated with overgrowth of Propionibacterium acnes and Staphylococcus epidermidis, is commonly treated with antibiotics. However, the emergence of antibiotic resistance has resulted in a need for alternative therapies. The aim of this study is to develop a topical preparation incorporating Essential Oils (EOs) for use against acne-associated bacteria and assess its efficacy against prescription therapies Dalacin $\mathrm{T}$ and Stiemycin. Antimicrobial screening of rosewood, clove bud and litsea EOs against was conducted before interactions between binary and ternary combinations were determined against $P$. acnes and $S$. epidermidis (type and clinical isolates) using Minimum Inhibitory Concentrations (MICs) and Fractional Inhibitory Concentrations (FICs). The EOs were characterised by both GC-MS and NMR. A combination of $0.53 \mathrm{mg} / \mathrm{ml}$ litsea, $0.11 \mathrm{mg} / \mathrm{ml}$ rosewood and $0.11 \mathrm{mg} / \mathrm{ml}$ clove bud was formulated into herbal distillates and compared to Dalacin $\mathrm{T}$ and Stiemycin against antibiotic sensitive and resistant isolates (erythromycin). The distillate with EO had synergistic activity against $P$. acnes ( $7 \log _{10}$ reduction) and indifferent activity against $S$. epidermidis (6 $\log _{10}$ reduction), antimicrobial activity was either significantly $(\mathrm{p} \leq 0.05)$ more antimicrobial or equivalent to that of Dalacin $\mathrm{T}$ and Stiemycin. This formulation may serve as a valuable alternative for the control of acne vulgarisassociated bacteria.
\end{abstract}




\section{INTRODUCTION}

Acne vulgaris, a chronic inflammatory disease of the pilosebaceous unit (Williams et al., 2012), affects approximately $80 \%$ of all 11 to 30 year olds (Bergler-Czop, 2014). The disease manifests as seborrhoea, non-inflammatory lesions (comedones), inflammatory lesions (papules, pustules, nodules and cysts), and scarring on the face, neck, chest and back (Williams et al., 2012), and is associated with substantial physical and psychological morbidity (Koo et al., 2014).

The pathogenesis of acne vulgaris is not fully understood, however, increased sebum production and follicular hyperkeratosis provides an anaerobic, lipid-rich environment in which the anaerobic commensal Propionibacterium acnes proliferates and stimulates inflammation (Contastot and French, 2014). In addition, Staphylococcus epidermidis, an aerobic skin commensal, may be a secondary coloniser that potentiates inflammation (BekThomsen et al., 2008).

Topical and oral antibiotics, such as tetracyclines or erythromcyin, are commonly prescribed for acne as they inhibit the proliferation of $P$. acnes and exert anti-inflammatory activity (Dawson and Dellavalle, 2013). However, resistance to these antibiotics has been observed in P. acnes; resistance to at least one antibiotic was found in 51-94\% of isolates in 6 European countries and was strongly correlated with prescribing patterns (Ross et al., 2003). Antibiotic resistance in $S$. epidermidis and other coagulase-negative staphylococci also increases in prevalence with the duration of therapy (Humphrey, 2012). This provides a rationale for seeking alternative antimicrobial treatments for acne vulgaris.

Essential oils (EOs) are volatile mixtures of plant secondary metabolites obtained by steam distillation of plant material (Solorzano-Santos and Miranda-Novales, 2012). Many EOs possess broad-spectrum antimicrobial activity, including against antibiotic resistant strains, in 
vitro. For example, lemongrass (Cymbopogon flexuosus) EO inhibited methicillin-sensitive Staphylococcus aureus and methicillin-resistant S. aureus (MRSA) at 0.06\% (Adukwu et al., 2012). While long term use of synthetic antibiotics is linked to resistance, EOs are complex mixtures and are believed to have multiple non-specific mechanisms of action, suggesting resistance may be less likely to develop (Alexopoulos et al., 2011). To date, no significant antimicrobial resistance to EOs has been reported (Bakkali et al., 2008). Furthermore, EOs often possess other pharmacological activities, such as anti-inflammatory activity, which may enhance their therapeutic benefits as acne treatments (Tsai et al., 2011).

This study aims to identify a synergistic antimicrobial combination of EOs against $P$. acnes and S. epidermidis, and analyse its in vitro efficacy in natural product-based topical formulations. The efficacy of the most active topical formulation was then compared to that of the topical antibiotic solutions Dalacin $\mathrm{T}$ and Stiemycin and their respective active ingredients, clindamycin phosphate and erythromycin.

\section{MATERIALS AND METHODS}

Essential Oils. Clove bud (Syzigum aromaticum), litsea (Litsea cubeba) and rosewood (Aniba rosaeadora) EOs were obtained from Penny Price Aromatherapy Ltd. (Hinckley, UK).

Gas Chromatographic Analysis. Major components of EOs were determined using a Thermo Focus gas chromatograph (GC) equipped with a flame ionization detector and Zebron ZB-5MS column (30m x $0.25 \mathrm{~mm}, 0.25 \mu \mathrm{m}$ film thickness). EO samples were diluted 1:100 in GC-grade hexane (Fisher Scientific, Loughborough, UK) and $0.30 \mathrm{ml}$ volumes injected into the GC. Injection temperature was $280^{\circ} \mathrm{C}$ and the split ratio $1: 34$. The column temperature was retained at $60^{\circ} \mathrm{C}$ for 5 minutes, before increasing to $220^{\circ} \mathrm{C}$ at a rate of $4^{\circ} \mathrm{C} / \mathrm{min}$, and to $280^{\circ} \mathrm{C}$ at a rate of $11^{\circ} \mathrm{C} / \mathrm{min}$. Identification of major components was based 
on comparisons to standard reference samples (Sigma Aldrich, Gillingham, UK) where possible. GC coupled with mass spectrometry (GC-MS) was performed using a Bruker 450GC gas chromatograph coupled with a Bruker 300-MS SQ mass spectrometer (Bruker, Billerica, USA) in order to identify remaining major components by NIST library database matching.

${ }^{1}$ H NMR Measurements. Proton $\left({ }^{1} \mathrm{H}\right)$ NMR measurements of EOs were conducted on a Bruker Avance $400 \mathrm{MHz}$ spectrometer operating at a frequency of $399.94 \mathrm{MHz}$ and a probe temperature of $298 \mathrm{~K}$. A $0.20 \mathrm{ml}$ aliquot of each EO sample was diluted to a final volume of $0.60 \mathrm{ml}$ with deuterated chloroform $\left(\mathrm{C}^{2} \mathrm{HCl}_{3}\right)$ containing $3.67 \times 10^{-3} \mathrm{~mol} . \mathrm{dm}^{-3}$ tetramethylsilane (TMS), the former providing a field frequency lock, the latter as an internal chemical shift reference $(\delta=0.00 \mathrm{ppm})$ and quantitative ${ }^{1} \mathrm{H}$ NMR standard; these solutions were then placed in $5 \mathrm{~mm}$ diameter NMR tubes. Typical pulsing conditions were: 128 free induction decays (FIDs) using 65,536 data points and a $4.5 \mathrm{~s}$ pulse repetition rate, the latter to allow full spin-lattice $\left(\mathrm{T}_{1}\right)$ - relaxation of protons in the samples investigated. Chemical shift values of resonances were referenced to TMS $(\delta=0.000 \mathrm{ppm}$, internal $)$ and/or residual chloroform $(\delta=7.262 \mathrm{ppm})$. Resonances present in each spectrum were routinely assigned by a consideration of chemical shift values, coupling patterns and coupling constants.

Microorganisms and Culture Methods. Test species were P. acnes (NCTC 737) and $S$. epidermidis (NCTC 7291). Clinical isolates obtained from Leicester Royal Infirmary (Leicester, UK) were S. epidermidis PL02202 (erythromycin-sensitive), PL021862 (erythromycin-resistant) and PL022186 (erythromycin-resistant), and P. acnes PL017109 (erythromycin-sensitive). All microorganisms were grown in brain heart infusion (BHI) broth and cultured on solid media using BHI agar (Sigma Aldrich). P. acnes NCTC 737 was grown in a $\mathrm{CO}_{2}$ incubator (Innova CO-170, New Brunswick Scientific, Edison, USA) at $37^{\circ} \mathrm{C}$, and P. acnes PL017109 in an anaerobic cabinet (MiniMACS Anaerobic Workstation, Don 
Whitley Scientific, Shipley, UK). S. epidermidis was grown under aerobic conditions at $37^{\circ} \mathrm{C}$.

Screening EOs for Antimicrobial Activity. A Kirby-Bauer disc diffusion method was used. Agar plates were spread with $0.10 \mathrm{ml}$ test bacterial culture before $2 \mathrm{~cm}$ filter paper discs spotted with $0.05 \mathrm{ml}$ EO were placed on the agar surface. Plates were incubated for $24 \mathrm{hr}$. at $37^{\circ} \mathrm{C}$ and zone of inhibition (ZOI) measured for each EO tested.

\section{Determination of Minimum Inhibitory Concentrations (MIC) and Minimum}

Bactericidal Concentrations (MBC) of EOs. Serial two-fold dilutions of EOs (litsea: 0.53$35.6 \mathrm{mg} / \mathrm{ml}$; rosewood and clove bud: $0.66-44 \mathrm{mg} / \mathrm{ml}$ ) were prepared in BHI broth with $10 \%$ (v/v) dimethyl sulfoxide (Fisher Scientific) to a final volume of $9.90 \mathrm{ml}$. A $0.10 \mathrm{ml}$ aliquot of either $P$. acnes $\left(10^{6}\right.$ colony forming units $\left.(\mathrm{CFU}) / \mathrm{ml}^{-1}\right)$ or $S$. epidermidis $\left(10^{5} \mathrm{CFU} / \mathrm{ml}^{-1}\right)$ was added before incubation at $37^{\circ} \mathrm{C}$ for $24 \mathrm{hr}$. Controls were BHI broth with $10 \%$ (v/v) dimethyl sulfoxide and $0.10 \mathrm{ml}$ organism only. MICs were determined as the lowest concentration of EO where no bacterial growth was observed. MBCs were determined by sub-culturing 0.10 $\mathrm{ml}$ aliquots of the test solutions after incubation onto BHI agar plates, which were then incubated for $24 \mathrm{hr}$. and any growth observed.

Assessment of Synergistic Antimicrobial Interactions. The checkerboard method (Mulyaningsih et al., 2010) was used to investigate potential synergistic, indifferent or antagonistic relationships between binary and ternary combinations of EOs by determination of Fractional Inhibitory Concentrations (FIC) and FICIs. Serial two-fold dilutions of EOs to yield final concentrations between the MIC and $0.89 \mathrm{mg} / \mathrm{ml}$ for litsea and $0.11 \mathrm{mg} / \mathrm{ml}$ for rosewood and clove bud EOs were prepared in BHI broth with $10 \%(\mathrm{v} / \mathrm{v})$ dimethyl sulfoxide and inoculated with either $P$. acnes or S. epidermidis. Binary and ternary combinations of these variable concentrations were added to 96 -well plates. The optical densities $(595 \mathrm{~nm})$ of the samples were obtained using a Spectramax Plus 384 microplate reader and Softmax Pro 
version 6.4 software (Molecular Devices, Sunnyvale, USA) at $0 \mathrm{hr}$., and again after $24 \mathrm{hr}$. incubation at $37^{\circ} \mathrm{C}$.

MICs and FICIs of the combinations of the EOs were then calculated:

$$
\mathrm{FICI}=\mathrm{FIC}_{\mathrm{EO} 1}+\mathrm{FIC}_{\mathrm{EO} 2}=\frac{\mathrm{MIC}_{\mathrm{EO} 1} \text { in combination }}{\mathrm{MIC}_{\mathrm{EO} 1} \text { alone }}+\frac{\mathrm{MIC}_{\mathrm{EO} 2} \text { in combination }}{\mathrm{MIC}_{\mathrm{EO} 2} \text { alone }}
$$

Synergistic, indifferent or antagonistic interactions were concluded from the following limits: Synergy: FICI $\leq$ 0.5, indifferent: $0.5>$ FICI $<4$, antagonism: FICI $>4$ (Odds, 2003). FIC data for each EO in the ternary combination was then employed to generate $3 \mathrm{D}$ isobolograms (Yoon et al., 2004) using Minitab version 17.2.1 (Minitab Inc., State College, USA).

Efficacy of EO Blend within Topical Formulations. A ternary combination of 0.53 $\mathrm{mg} / \mathrm{ml} \mathrm{litsea,} 0.11 \mathrm{mg} / \mathrm{ml}$ clove bud and $0.11 \mathrm{mg} / \mathrm{ml} \mathrm{rosewood} \mathrm{EOs} \mathrm{found} \mathrm{to} \mathrm{inhibit} \mathrm{both} P$. acnes and S. epidermidis was tested for antimicrobial activity in two topical cosmetic toner preparations comprising of either neroli (Citrus aurantium var amara) or Roman chamomile (Chamaemelum nobile) herbal distillate (hydrolat) with $0.5 \%(\mathrm{v} / \mathrm{v})$ ethanol (Fisher Scientific) added as an EO solvent. A method adapted from the British Standard preservative efficacy test (British Standards Institute, 2012) was used. Formulations were prepared and inoculated with either $P$. acnes $\left(10^{7} \mathrm{CFU} / \mathrm{ml}^{-1}\right)$ or $S$. epidermidis $\left(10^{6} \mathrm{CFU} / \mathrm{ml}^{-1}\right)$ before being incubated for $24 \mathrm{hr}$. at either $25^{\circ} \mathrm{C}$ (skin surface temperature) or $37^{\circ} \mathrm{C}$ (pilosebaceous unit temperature), spread plated onto BHI agar and enumerated. This was repeated with the most efficacious topical preparation against $P$. acnes and $S$. epidermidis clinical isolates. Controls were hydrolat alone and hydrolat with $0.5 \%(\mathrm{v} / \mathrm{v})$ ethanol.

Comparison of Efficacy of Neroli Toner to Current Prescription Therapies. The antimicrobial efficacy of the neroli toner was compared to the prescription only topical antibiotic preparations Dalacin $\mathrm{T}$ and Stiemycin by determining $\log _{10} \mathrm{CFU} / \mathrm{ml}$ reductions of S. epidermidis and P. acnes type strains together with clinical isolates S. epidermidis 
PL021862, PL022186 and PL02202 and P. acnes PL017109 after $24 \mathrm{hr}$. incubation at $25^{\circ} \mathrm{C}$ and $37^{\circ} \mathrm{C}$ according to the adapted British Standard preservative efficacy test method. In addition, the ternary combination of $0.53 \mathrm{mg} / \mathrm{ml}$ litsea, $0.11 \mathrm{mg} / \mathrm{ml}$ clove bud and $0.11 \mathrm{mg} / \mathrm{ml}$ rosewood EOs was compared to that of the Dalacin T and Stiemycin active ingredients, 10 $\mathrm{mg} / \mathrm{ml}$ clindamycin phosphate and $20 \mathrm{mg} / \mathrm{ml}$ erythromycin (Sigma Aldrich), respectively. Active ingredients were suspended in BHI broth and $0.5 \%(\mathrm{v} / \mathrm{v})$ ethanol was used as a solvent for the EO combination. Controls were BHI broth with $0.5 \%(\mathrm{v} / \mathrm{v})$ ethanol, and BHI broth alone.

All investigations were carried out in triplicate on at least two separate occasions.

Statistical Analysis. Two-way analysis of variance with Tukey's comparisons was conducted using Minitab Statistical Software version 16 (Minitab Inc., State College, USA) in order to determine the significance of any differences $(p \leq 0.05)$ in mean $\log _{10}$ reductions between topical preparations and their controls.

\section{RESULTS AND DISCUSSION}

Antimicrobial Activity of EOs. Initial screening showed that clove bud, litsea and rosewood had mean ZOIs of $3.9 \mathrm{~mm} \pm 0.03,9.0 \mathrm{~mm} \pm 0.00$ and $9.0 \mathrm{~mm} \pm 0.00$ for P. acnes, and $2.8 \mathrm{~mm} \pm 0.03,1.7 \mathrm{~mm} \pm 0.06$ and $3.2 \mathrm{~mm} \pm 0.03$ against $S$. epidermidis.

MICs of clove bud and rosewood EOs were $1.38 \mathrm{mg} / \mathrm{ml}$ against both $S$. epidermidis and $P$. acnes. Litsea had an MIC of $1.11 \mathrm{mg} / \mathrm{ml}$ against $S$. epidermidis; however, it exerted less antimicrobial activity against $P$. acnes $(\mathrm{MIC}=2.23 \mathrm{mg} / \mathrm{ml})$. EOs were bactericidal against $S$. epidermidis, with MBCs of $2.23 \mathrm{mg} / \mathrm{ml}$ for litsea, and $2.75 \mathrm{mg} / \mathrm{ml}$ for rosewood and clove bud EOs, however, only the clove bud EO was bactericidal against P. acnes $(\mathrm{MBC}=5.5$ $\mathrm{mg} / \mathrm{ml})$. Previous investigations have reported MICs of $0.25 \%(\mathrm{v} / \mathrm{v})$ for clove bud EO against 
S. epidermidis (Fu et al., 2007) in accordance with the current findings. However, the MIC of clove bud EO against $P$. acnes was greater than the previously reported MIC of $0.31 \mathrm{mg} / \mathrm{ml}$ $\mathrm{Fu}$ et al., 2009) which may be the result of variation in isolate susceptibility or EO composition between studies (Verma et al., 2015). Antimicrobial activity of litsea and rosewood EOs has been reported against species such as $S$. aureus (MICs $=0.2$ and 0.5 mg/ml, respectively; Wang and Liu, 2010; Rosato et al., 2010)

\begin{abstract}
Assessment of Synergistic Antimicrobial Interactions Between EOs. Synergistic interactions were observed between all binary combinations of litsea, clove bud and rosewood EOs against $S$. epidermidis. MICs of these EOs in combination were $0.11 \mathrm{mg} / \mathrm{ml}$ rosewood with $0.33 \mathrm{mg} / \mathrm{ml}$ clove bud $($ FICI $=0.32)$, and $0.09 \mathrm{mg} / \mathrm{ml} \mathrm{litsea} \mathrm{with} 0.11 \mathrm{mg} / \mathrm{ml}$ rosewood $(\mathrm{FICI}=0.16)$ or $0.33 \mathrm{mg} / \mathrm{ml}$ clove bud $\mathrm{EO}(\mathrm{FICI}=0.32)$. A combination of litsea $(0.53 \mathrm{mg} / \mathrm{ml})$ and rosewood EOs $(0.33 \mathrm{mg} / \mathrm{ml})$ was synergistic against $P$. acnes $($ FICI $=0.48)$, however, combinations containing clove bud EO were indifferent (FICIs $=0.58-1.08$ ). Synergistic binary combinations of bergamot (C. bergamia) and basil (Ocimum basilicum) EOs reportedly engendered a greater leakage of cellular contents of B. subtilis, E. coli and S. aureus compared to EOs alone, suggesting enhanced cell membrane disintegration (Lv et al., 2011). Furthermore, disintegration of the membrane by one component may increase the cellular uptake of other antimicrobial components (Santiesteban-Lopez et al., 2007).
\end{abstract}

A combination of $0.53 \mathrm{mg} / \mathrm{ml}$ litsea, $0.11 \mathrm{mg} / \mathrm{ml} \mathrm{rosewood} \mathrm{and} 0.11 \mathrm{mg} / \mathrm{ml}$ clove bud EOs was synergistic against $P$. acnes $($ FICI $=0.40$ ), whilst a combination of $0.09 \mathrm{mg} / \mathrm{ml}$ litsea, $0.11 \mathrm{mg} / \mathrm{ml}$ clove bud and $0.11-0.33 \mathrm{mg} / \mathrm{ml}$ rosewood EOs was synergistic against $S$. epidermidis $(\mathrm{FICI}=0.24)$, as illustrated by concave areas of 3D isobolograms (Figures 1a and $1 \mathrm{~b})$. The lowest combination of EOs required to inhibit both test species was $0.53 \mathrm{mg} / \mathrm{ml}$ litsea, $0.11 \mathrm{mg} / \mathrm{ml}$ rosewood and $0.11 \mathrm{mg} / \mathrm{ml}$ clove bud EOs. As such, the quantity of EOs 
required to inhibit these microorganisms was further reduced, which may decrease the likelihood of adverse effects with topical application (Casetti et al., 2012).

Chemical Composition of EOs. GC analysis indicated that citral was the most abundant compound present in litsea EO (49.64\%), while eugenol was most abundant in clove bud EO (60.90\%), and linalool represented the predominant agent present in rosewood EO $(86.73 \%)$, in accordance with previous research (Fu et al., 2007; Rosato et al., 2010; Wang and Liu, 2010). ${ }^{1} \mathrm{H}$ NMR spectroscopy data acquired is in agreement with that from GC analysis (Figure 2).

\section{Antimicrobial Efficacy of the Ternary EO Combination in Cosmetic Toner Topical}

Formulations. The ternary combination of EOs was tested for antimicrobial activity in two toner formulations based on neroli or Roman chamomile hydrolats. Hydrolats are waterbased by-products of steam distillation of plant material, and contain some water-soluble components of EOs (Lin et al., 2011). Both hydrolats were antimicrobial, resulting in reductions of between 0.67 and $4.76 \log _{10}$ (Table 1). Few studies have investigated the antimicrobial activity of hydrolats; however, Chinese olive (Canarium album) hydrolat was reportedly antimicrobial against $P$. acnes and $S$. epidermidis $(\mathrm{ZOIs}=15.2 \mathrm{~mm}$ and $21.0 \mathrm{~mm}$, respectively; Lin et al., 2011). Temperature did not significantly ( $\mathrm{p} \geq 0.05)$ affect the activity of Roman chamomile hydrolat, however, activity of neroli hydrolat was significantly ( $\mathrm{p} \leq$ $0.05)$ increased at $37^{\circ} \mathrm{C}$.

Ethanol $(0.5 \% \mathrm{v} / \mathrm{v})$ was added to the hydrolat as an EO solvent. This concentration of ethanol was not antimicrobial (data not shown), however significantly $(\mathrm{p} \leq 0.05)$ increased the activity of neroli hydrolat against $S$. epidermidis and $P$. acnes, resulting in complete inhibition of $P$. acnes at $37^{\circ} \mathrm{C}$ and $S$. epidermidis at both temperatures. Furthermore, Roman chamomile hydrolat was significantly $(\mathrm{p} \leq 0.05)$ more antimicrobial against $S$. epidermidis 
with the addition of ethanol, with 5.5 and $5.2 \log _{10}$ reductions being observed at $25^{\circ} \mathrm{C}$ and $37^{\circ} \mathrm{C}$, respectively. Although antimicrobial interactions between ethanol and hydrolats have not previously been studied, a non-lethal concentration of ethanol was synergistic with the lipid sapienic acid against MRSA. Ethanol is a penetration enhancer, and in this manner may increase partitioning of antimicrobial components into the cell membrane or enhance entry into the cytoplasm (Drake et al., 2008).

The complete toner formulations (hydrolat, ethanol and EOs) completely destroyed $P$. acnes at $25^{\circ} \mathrm{C}$. This was significantly $(\mathrm{p} \leq 0.05)$ greater than reductions achieved by hydrolat with ethanol, suggesting that EOs significantly contribute to the antimicrobial activity of the formulation. S. epidermidis was also completely destroyed by neroli and Roman chamomile toners; this activity was equivalent $(\mathrm{p} \geq 0.05)$ to that of a combination of hydrolat with ethanol, indicating that the EOs do not provide any additional benefit to the topical formulation for the control of S. epidermidis.

Additionally, the neroli toner with EOs completely inhibited all three clinical isolates of $S$. epidermidis, and one of $P$. acnes, including the antibiotic resistant strains $S$. epidermidis PL021862 and PL022186. Considering the variation in antimicrobial susceptibility of isolates from individual acne patients, and between patients (Humphrey, 2012) this data demonstrates the potential use of this formulation as a novel product for the control of $P$. acnes and $S$. epidermidis.

Comparison of Neroli Toner Efficacy to that of Dalacin $\mathbf{T}$ and Stiemycin. The topical antibiotic solutions Dalacin $\mathrm{T}$ and Stiemycin resulted in complete inhibition of all test species. The neroli toner formulation possesses an equivalent antimicrobial activity (Table 1), further supporting its use for the control of acne vulgaris. 
Comparison of the Neroli Toner, Dalacin T and Stiemycin Active Ingredients. Overall, there was a high level of variability in antimicrobial activity between the active ingredients, which was dependent on strain/isolate and incubation temperature (Table 2). Erythromycin produced significantly $(\mathrm{p} \leq 0.05)$ greater reductions than clindamycin phosphate and EOs against S. epidermidis PL021862 at $37^{\circ} \mathrm{C}$, and S. epidermidis PL02202 and P. acnes type strain, at both temperatures (Table 2). Interestingly, erythromycin completely inhibited the erythromycin-resistant S. epidermidis isolate PL021862 at $37^{\circ} \mathrm{C}$. However, the concentration of $20 \mathrm{mg} / \mathrm{ml}$ found in Stiemycin is significantly greater than the MIC breakpoint for resistance to erythromycin of $2 \mathrm{mg} / \mathrm{ml}$ in staphylococci (BSAC, 2015). EOs were significantly $(\mathrm{p} \leq 0.05)$ less antimicrobial than clindamycin phosphate against $S$. epidermidis PL021862 and $P$. acnes at $37^{\circ} \mathrm{C}$. However, EOs were not significantly ( $\left.\mathrm{p} \geq 0.05\right)$ different in activity to clindamycin phosphate against S. epidermidis isolate PL021862 at $25^{\circ} \mathrm{C}$, and PL022186 and PL02202 at both temperatures. Furthermore, EOs were significantly ( $\mathrm{p} \leq$ 0.05) more antimicrobial than clindamycin phosphate against $P$. acnes at $25^{\circ} \mathrm{C}$, and both antibiotics against the P. acnes clinical isolate PL017109 and S. epidermidis type strain, indicating that the EOs could be useful as novel antibiotic alternatives.

$\log _{10} \mathrm{CFU} / \mathrm{ml}$ reductions achieved by all three active ingredients were significantly $(\mathrm{p} \leq$ 0.05) lower than the complete inhibition achieved by their complete formulations. Dalacin T contains 50\% (v/v) isopropyl alcohol, and Stiemycin contains absolute ethanol (unspecified quantity), which are both bactericidal agents and may increase the antimicrobial activity of the complete formulations over that of their active ingredients. The combination of neroli hydrolat and ethanol were demonstrated to be significantly antimicrobial and hence increase the antimicrobial activity of the toner when incorporated (Table 1). This indicates that the complete formulation is essential to the inhibition of bacteria contributing to acne vulgaris. 
Novel antibiotic alternatives for the control of acne vulgaris-associated bacteria are required to combat antibiotic resistance. In this study, a neroli toner formulation was equivalent in activity to two current topical antibiotic solutions, including against erythromycin-resistant clinical isolates of $S$. epidermidis. The active ingredients of the neroli toner, a ternary combination of litsea, clove bud and rosewood EOs, had equivalent or even greater antimicrobial activity than that of clindamycin phosphate, erythromycin, or both against all but the $P$. acnes type strain at $37^{\circ} \mathrm{C}$, and one clinical isolate of $S$. epidermidis. Therefore, the toner formulation may be a useful novel alternative for the control of acne vulgaris-associated bacteria.

\section{ACKNOWLEDGEMENTS}

This work was supported by the European Regional Development Fund (ERDF) Partnerships in Knowledge Transfer Scheme.

Conflict of Interest

P. Price is an employee of Penny Price Aromatherapy which in part funded the ERDF Partnerships in Knowledge Transfer Scheme. The experimental aspect of the research was conducted by academics and was fully objective.

\section{REFERENCES}

Adukwu EC, Allen SCH, Phillips CA. 2012. The anti-biofilm activity of lemongrass (Cymbopogon flexuosus) and grapefruit (Citrus paradisi) essential oils against five strains of Staphylococcus aureus. J Appl Microbiol 113: 1217-1227.

Alexopoulos AC, Kimbaris AC, Plessas S, Mantzourani I, Theodoridou I, Stavropoulou E, Polissiou MG, Bezirtzoglou, E. 2011. Antibacterial activities of essential oils from eight 
Greek aromatic plants against clinical isolates of Staphylococcus aureus. Anaerobe 17: 399402.

Bakkali F, Averbeck S, Averbeck D, Idaomar M. 2008. Biological effects of essential oils a review. Food Chem Toxicol 46: 446-475.

Bek-Thomsen M, Lomholt HB, Kilian, M. 2008. Acne is not associated with yet-uncultured bacteria. J Clin Microbiol, 46: 3355-3360.

Bergler-Czop B. 2014. The aetiopathogenesis of acne vulgaris - what's new? Int J Cosmetic Sci 36: 187-194.

British Society for Antimicrobial Chemotherapy, Standing Committee on Susceptibility Testing, 14.3. British Society for Antimicrobial Chemotherapy: Birmingham, UK, 2015.

British Standards Institute. 2014. BS EN ISO 11930:2012. ISO Copyright Office: Switzerland.

Casetti F, Bartelke S, Biehler K, Augustin M, Schempp CM, Frank U. 2012. Antimicrobial activity against bacteria with dermatological relevance and skin tolerance of the essential oil from Coriandrum sativum L. fruits. Phytother Res 26: 420-424.

Chambers ST, Pithie A, Gallagher K, Liu T, Charles C.J, Seaward L. 2007. Treatment of Staphylococcus epidermidis central vascular catheter infections with $70 \%$ ethanol locks: efficacy in a sheep model. J Antimicrob Chemother 59: 779-782.

Contasot E, French LE. 2014. New insights into acne pathogenesis: Propionibacterium acnes activates the inflammasome. J Invest Dermatol 134: 310-313.

Dawson AL, Dellavalle RP. 2013. Acne vulgaris. BMJ 346: f2634.

Drake DR, Brogden KA, Dawson DV, Wertz PW. 2008. Thematic Review Series: Skin Lipids. Antimicrobial lipids at the skin surface. J Lipid Res 49: 4-11. 
Fu Y, Chen L, Zu Y, Liu Z, Liu X, Liu Y, Yao L, Efferth T. 2009. The antibacterial activity of clove essential oil against Propionibacterium acnes and its mechanism of action. Arc Dermatol 145: 86-88.

Fu Y, Zu Y, Chen L, Shi X, Wang Z, Sun S, Efferth T. 2007. Antimicrobial activity of clove and rosemary essential oils alone and in combination. Phytother Res 21: 989-994.

Humphrey S. 2012. Antibiotic resistance in acne treatment. Skin Therapy Lett 17: 1-3.

Koo EB, Petersen TD, Kimball AB. 2014. Meta-analysis comparing efficacy of antibiotics versus contraceptives in acne vulgaris. $J$ Am Acad Dermatol 71: 450-459.

Lin CC, Yang CH, Wu PS, Kwan CC, Chen YS. 2011. Antimicrobial, anti-tyrosinase and antioxidant activities of aqueous aromatic extracts from forty-eight selected herbs. $J$ Med Plant Res 5: 6203-6209.

Lv F, Liang H, Yuan Q, Li C. 2011. In vitro antimicrobial effects and mechanism of action of selected plant essential oil combinations against four food-related microorganisms. Food Res Int 44: 3057-3064.

Mulyaningsih S, Sporer F, Zimmermann S, Reichling J, Wink, M. 2010. Synergistic properties of the terpenoids aromadendrene and 1,8-cineole from the essential oil of Eucalyptus globulus against antibiotic-susceptible and antibiotic-resistant pathogens. Phytomedicine 17: 1061-1066.

Odds FC. 2003. Synergy, antagonism, and what the chequerboard puts between them. $J$ Antimicrob Chemoth 52: 1.

Rosato A, Piarulli M, Corbo F, Muaglia M, Carone A, Vitali ME, Vitali C. 2010. In vitro synergistic action of certain combinations of gentamycin and essential oil. Curr Med Chem 17: 3289-3295. 
Ross JJ, Snelling AM, Carnegie E, Coates P, Cunliffe WJ, Bettoli V, Tosti G, Katsambas A, Galvan Peréz Del Pugar JI, Rollman O, Török L, Eady EA, Cove JH. 2003. Antibioticresistant acne: lessons from Europe. Brit J Dermatol 148: 467-478.

Santiesteban-López A, Palou E, López-Malo A. 2007. Susceptibility of food-borne bacteria to binary combinations of antimicrobials at selected $\mathrm{a}_{\mathrm{w}}$ and $\mathrm{pH} . J$ Appl Microbiol 102: 486497.

Solorzano-Santos F, Miranda-Novales M. 2012. Essential oils from aromatic herbs as antimicrobial agents. Curr Opin Biotech 23: 136-141.

Tsai ML, Lin CC, Lin WC, Yang, CH. 2011. Antimicrobial, antioxidant, and antiinflammatory activities of essential oils from five selected herbs. Biosci Biotechnol Biochem 75: 1977-1983.

Verma RS, Padalia RC, Chauhan A. 2015. Harvesting season and plant part dependent variations in the essential oil composition of Salvia officinalis L. grown in northern India. $J$ Herb Med 5: 165-171.

Wang H, Liu Y. 2010. Chemical composition and antibacterial activity of essential oils from different parts of Litsea cubeba. Chem Biodivers 7: 229-237.

Williams HC, Dellavalle RP, Garner S. 2012. Acne vulgaris. Lancet 379: 361-372.

Yoon J, Urban C, Terzian C, Mariano N, Rahal JJ. 2004. In vitro double and triple synergistic activities of polymixin $\mathrm{B}$, imipenem, and rifampicin against multidrug-resistant Acinetobacter baumannii. Antimicrob Agents Chemother 48: 753-757.

http://mc.manuscriptcentral.com/ptr 
Table 1. $\log _{10}$ reductions of $P$. acnes and $S$. epidermidis in cosmetic toner formulations after $24 \mathrm{hr}$. incubation at $25^{\circ} \mathrm{C}$ and $37^{\circ} \mathrm{C}(\mathrm{n}=6$, mean $\pm \mathrm{SEM})$.

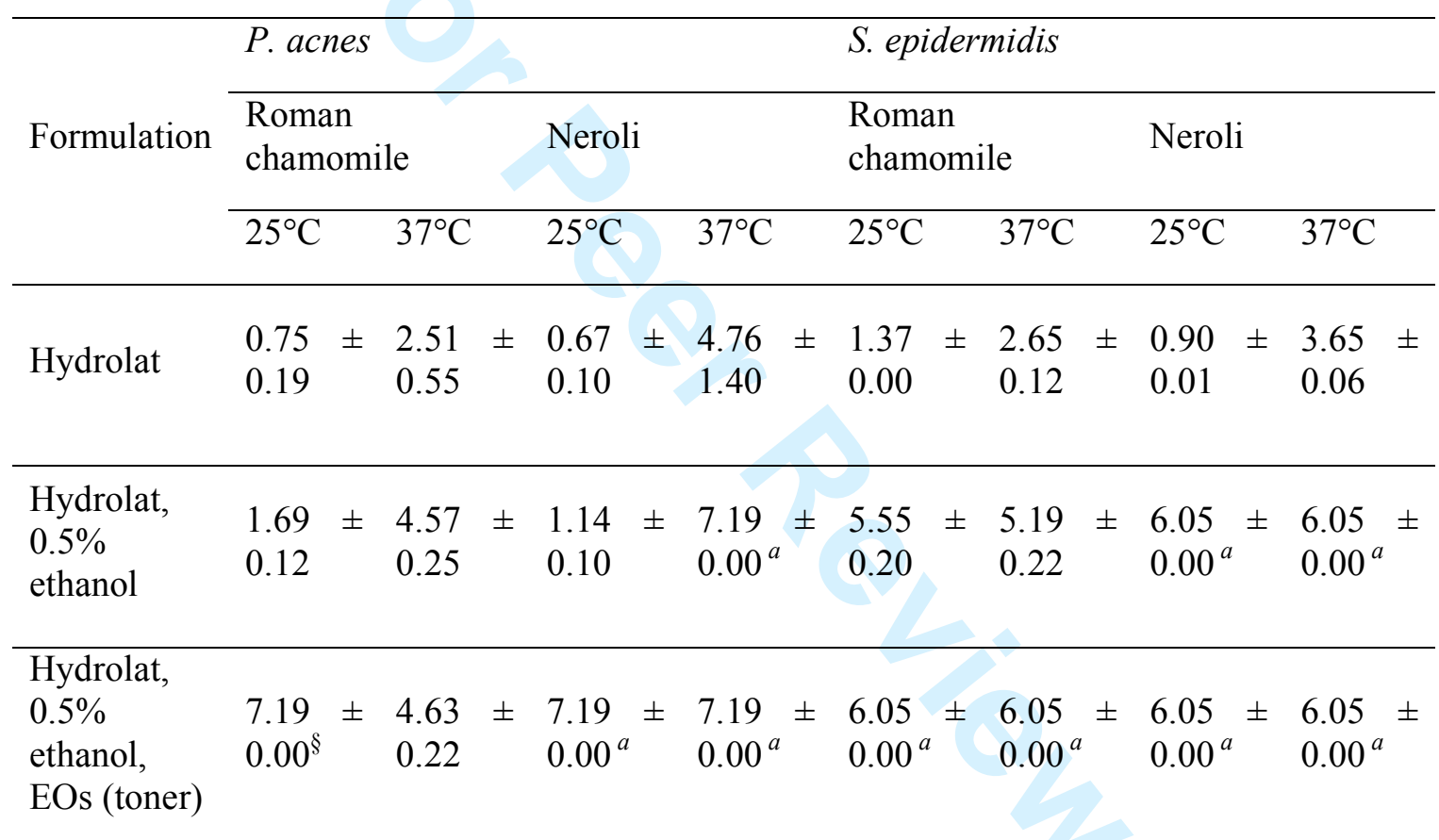

\footnotetext{
${ }^{a}$ Complete inhibition.
} 
Table 2. $\log _{10}$ reductions of $P$. acnes and S. epidermidis by active ingredients of the neroli toner, Dalacin T and Stiemycin at $25^{\circ} \mathrm{C}$ and $37^{\circ} \mathrm{C}(\mathrm{n}=6$, mean $\pm \mathrm{SEM})$.

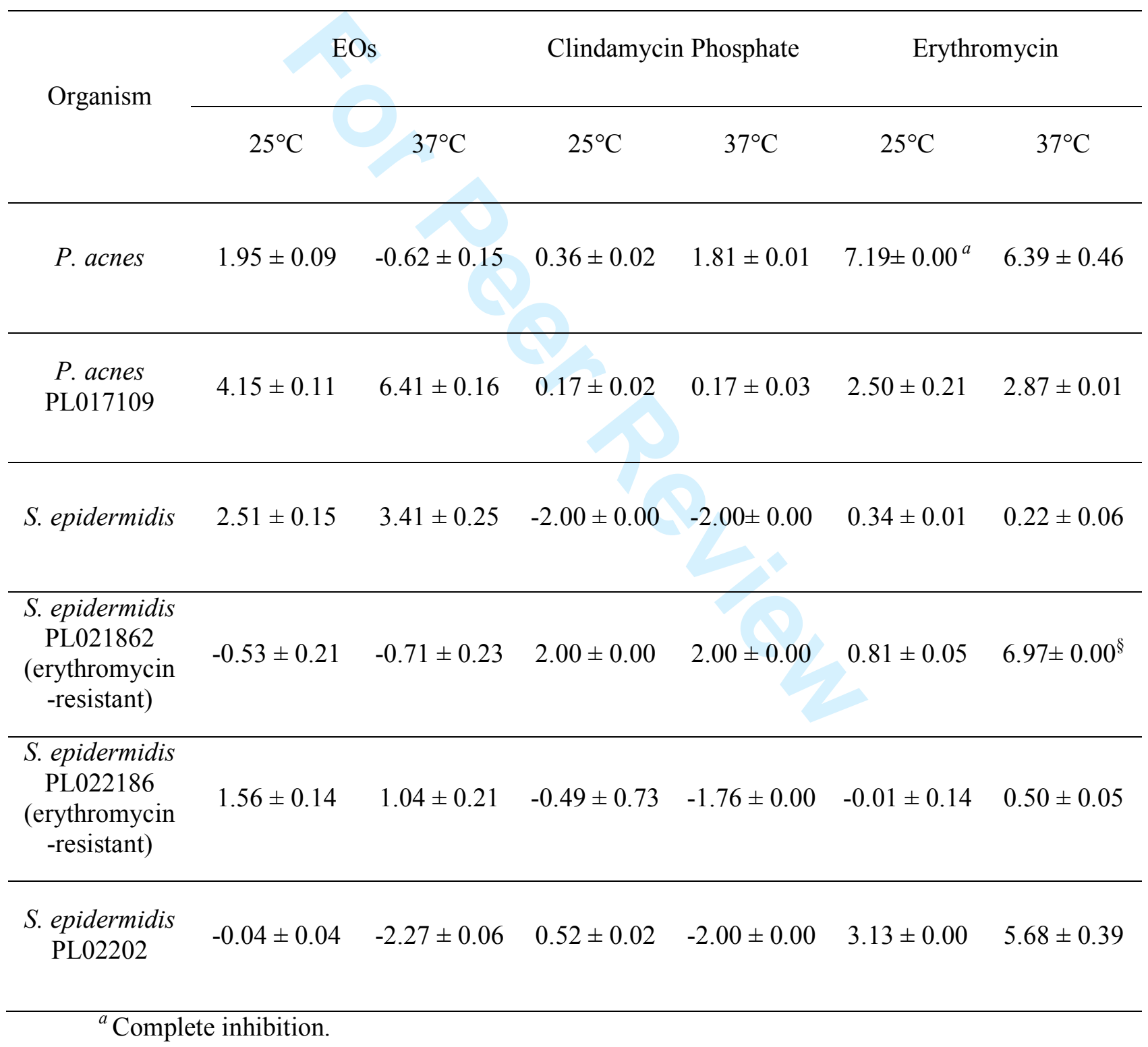


a)

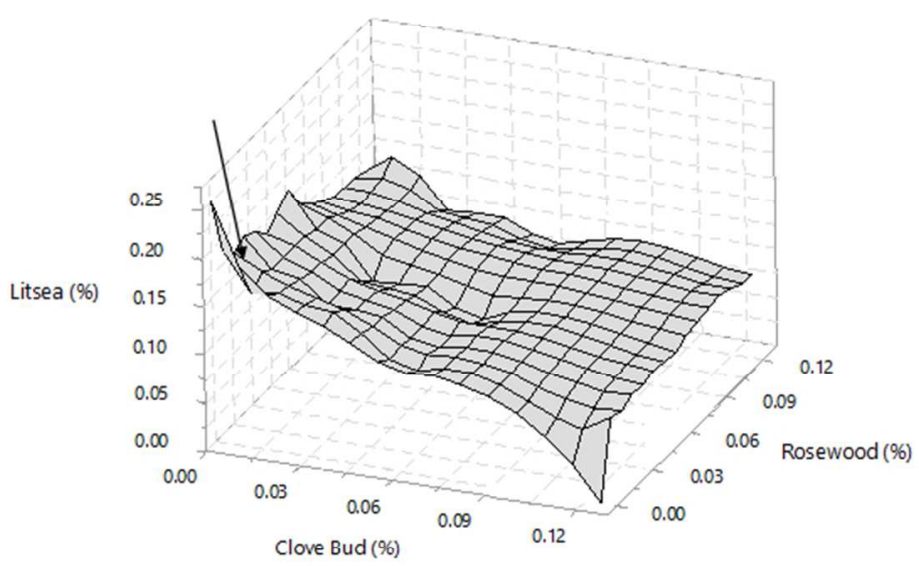

b)

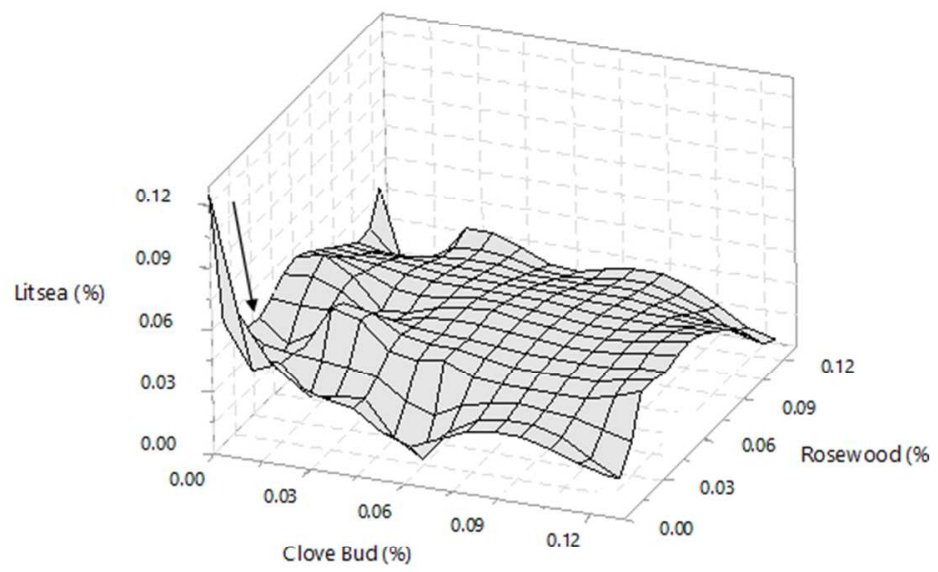

Lucy Owen. Figure 1: 3D plot of fractional inhibitory concentrations of litsea, rosewood and clove bud EOs against a) $P$. acnes and b) $S$. epidermidis.

Figure 1: 3D plot of fractional inhibitory concentrations of litsea, rosewood and clove bud EOs against a) $P$. acnes and b) S. epidermidis.

(Figures $1 \mathrm{a}$ and $1 \mathrm{~b}$ ). $153 \times 245 \mathrm{~mm}(96 \times 96$ DPI $)$ 
a)

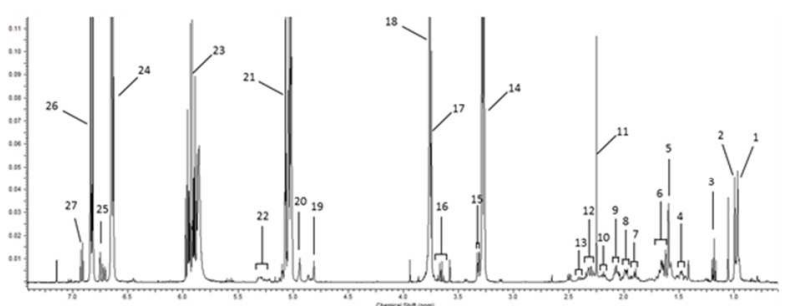

b)

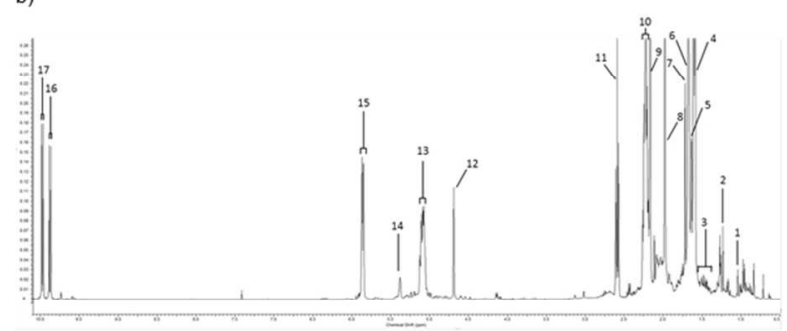

c)

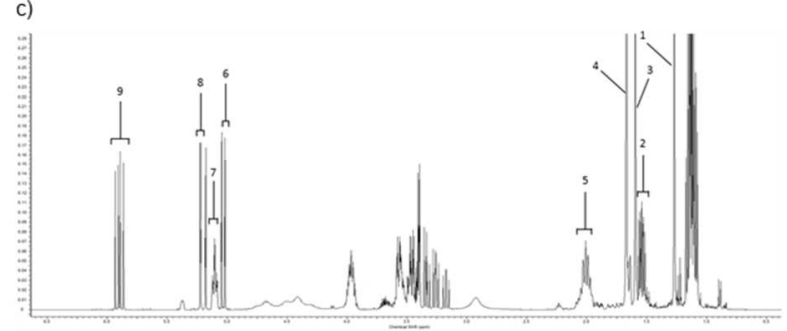

Lucy Owen. Figure 2: $400 \mathrm{MHz}{ }^{1} \mathrm{H}$ NMR spectra of a) clove, b) litsea and c) rosewood EOs.

\section{Assignments:}

a) $1, \beta \mathrm{C}-\mathrm{C} 14-\mathrm{CH}_{3} ; 2, \beta \mathrm{C}-\mathrm{C} 15-\mathrm{CH}_{3} ; 3$, Ethanol- $\mathrm{CH}_{3} ; 4, \beta \mathrm{C}-\mathrm{C} 2-\mathrm{CH}_{2 \mathrm{a}} ; 5, \mathrm{CC}-\mathrm{C} 13-\mathrm{CH}_{3}$, 6, $\beta \mathrm{C}-\mathrm{C} 2-\mathrm{CH}_{2 b} / \mathrm{C} 10-\mathrm{CH}_{2} ; 7, \beta \mathrm{C}-\mathrm{C} 3-\mathrm{CH}_{2 \mathrm{a}} ; 8, \beta \mathrm{C}-\mathrm{C} 6-\mathrm{CH}_{2 \mathrm{a}} ; 9, \beta \mathrm{C}-\mathrm{C} 3-\mathrm{CH}_{2 b} ; 10, \beta \mathrm{C}-\mathrm{C} 7-$ $\mathrm{CH}_{2 a} ; 11$, AcEug-CO-CH $3 ; 12, \beta \mathrm{C}-\mathrm{C} 7-\mathrm{CH}_{2 \mathrm{~b}} / \mathrm{C} 6-\mathrm{CH}_{2} ; 13, \beta \mathrm{C}-\mathrm{C} 9-\mathrm{CH} ; 14$, Eug-Ar- $\mathrm{CH}_{2}$; 15 , AcEug-Ar- $\mathrm{CH}_{2} ; 16$, Ethanol- $\mathrm{CH}_{2} \mathrm{OH} ; 17$, AcEug-O-CH 3 ; 18 , Eug-O- $\mathrm{CH}_{3} ; 19, \beta C$ C12- $\mathrm{CH}_{2 \mathrm{a}} ; 20, \beta \mathrm{C}-\mathrm{C} 12-\mathrm{CH}_{2 \mathrm{~b}}$; 21, Eug/Ac-Eug- $\mathrm{CH}_{2}=\mathrm{CH} ; 22, \beta \mathrm{C}-\mathrm{C} 5-\mathrm{CH} ; 23$, Eug/ACEug- $\mathrm{CH}_{2}=\mathrm{CH} ; 24$, Eug-Ar $1 ; 25$, AcEug-Ar $; 26$, Eug-Ar $; 27$, AcEug-Ar 2

b) 1, Euc-C11- $\mathrm{CH}_{3} ; 2$, Euc-C9/10-CH3's; 3 , Euc-C3-CH; 4, G-C8-CH / N-C8-CH;

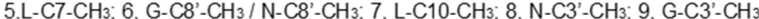
10 , N-C4/5- $\mathrm{CH}_{2}$ 'S / G-C5- $\mathrm{CH}_{2} ; 11$, G-C4- $\mathrm{CH}_{2} ; 12$, L-C7- $\mathrm{CH}_{2} ; 13, \mathrm{~N}-\mathrm{C} 6-\mathrm{CH} / \mathrm{G}-\mathrm{C} 6-$ $\mathrm{CH} ; 14, \mathrm{~L}-\mathrm{C} 2-\mathrm{CH} ; 15, \mathrm{~N}-\mathrm{C} 2-\mathrm{CH} / \mathrm{G}-\mathrm{C} 2-\mathrm{CH} ; 16, \mathrm{~N}-\mathrm{C} 1-\mathrm{CHO} ; 17,16$, G-C1-CHO

c) 1, Lin-C3-CH 3 ; 2 Lin-C4-CH 2 , 3, Lin- $\mathrm{C}_{-}-\mathrm{CH}_{3} ; 4$, Lin- $\mathrm{C} 8-\mathrm{CH}_{3} ; 5$, Lin- $\mathrm{C} 5-\mathrm{CH}_{2}$; 6 , Lin-

Figure 2: $400 \mathrm{MHz}{ }^{1} \mathrm{H}$ NMR spectra of a) clove, b) litsea and c) rosewood EOs

respectively. \%"Assignments: a) $1, \beta \mathrm{C}-\mathrm{C} 14-\mathrm{CH}_{3} ; 2, \beta \mathrm{C}-\mathrm{C} 15-\mathrm{CH}_{3} ; 3$, Ethanol- $\mathrm{CH}_{3} ; 4, \beta \mathrm{C}-\mathrm{C} 2-\mathrm{CH}_{2 \mathrm{a}} ; 5, \beta \mathrm{C}-$ $\mathrm{C} 13-\mathrm{CH}_{3} ; 6, \beta \mathrm{C}-\mathrm{C} 2-\mathrm{CH}_{2 \mathrm{~b}} / \mathrm{C} 10-\mathrm{CH}_{2} ; 7, \beta \mathrm{C}-\mathrm{C} 3-\mathrm{CH}_{2 \mathrm{a}} ; 8, \beta \mathrm{C}-\mathrm{C} 6-\mathrm{CH}_{2 \mathrm{a}} ; 9, \beta \mathrm{C}-\mathrm{C}_{3}-\mathrm{CH}_{2 \mathrm{~b}} ; 10, \beta \mathrm{C}-\mathrm{C}_{2} \mathrm{CH}_{2 \mathrm{a}} ; 11$, AcEug$\mathrm{CO}-\mathrm{CH}_{3} ; 12, \beta C-\mathrm{C} 7-\mathrm{CH}_{2 \mathrm{~b}} / \mathrm{C} 6-\mathrm{CH}_{2} ; 13, \beta \mathrm{C}-\mathrm{C} 9-\mathrm{CH} ; 14$, Eug-Ar- $\mathrm{CH}_{2} ; 15, \mathrm{AcEug}-\mathrm{Ar}-\mathrm{CH}_{2} ; 16$, Ethanol- $\mathrm{CH}_{2} \mathrm{OH}$; 17, AcEug-O-CH $\mathrm{CH}_{3} ; 18$, Eug-O- $\mathrm{CH}_{3} ; 19, \beta C C 12-\mathrm{CH}_{2 a} ; 20, \beta C-C 12-\mathrm{CH}_{2 b} ; 21$, Eug/Ac-Eug- $\mathrm{CH}_{2}=\mathrm{CH} ; 22, \beta C-\mathrm{C} 5-$ $\mathrm{CH} ; 23$, Eug/AcEug- $\mathrm{CH}_{2}=\mathrm{CH} ; 24$, Eug-Ar $;$; 25, AcEug-Ar 1 ; 26, Eug-Ar $; 27$, AcEug-Ar2. \%"b) 1, Euc-C11$\mathrm{CH}_{3} ; 2$, Euc-C9/10- $\mathrm{CH}_{3}$ 's; 3, Euc-C3-CH; 4, G-C8-CH $/ \mathrm{N}-\mathrm{C} 8-\mathrm{CH}_{3} ; 5, \mathrm{~L}-\mathrm{C} 7-\mathrm{CH}_{3} ; 6, \mathrm{G}-\mathrm{C}^{\prime}-\mathrm{CH}_{3} / \mathrm{N}-\mathrm{C}^{\prime}-\mathrm{CH}_{3} ; 7$, $\mathrm{L}-\mathrm{C}_{10}-\mathrm{CH}_{3} ; 8, \mathrm{~N}-\mathrm{C}^{\prime}-\mathrm{CH}_{3} ; 9, \mathrm{G}-\mathrm{C}^{\prime}-\mathrm{CH}_{3} ; 10, \mathrm{~N}-\mathrm{C} 4 / 5-\mathrm{CH}_{2}$ 's / G-C5- $\mathrm{CH}_{2} ; 11, \mathrm{G}-\mathrm{C}_{4}-\mathrm{CH}_{2} ; 12, \mathrm{~L}-\mathrm{C} 7-\mathrm{CH}_{2} ; 13, \mathrm{~N}-$ $\mathrm{C} 6-\mathrm{CH} / \mathrm{G}-\mathrm{C} 6 \mathrm{CH}$; 14, L-C2-CH; 15, N-C2-CH / G-C2-CH ; 16, N-C1-CHO; 17, 16, G-C1-CHO. \%"c) 1, Lin$\mathrm{C}_{3}-\mathrm{CH}_{3} ; 2$, Lin-C4- $\mathrm{CH}_{2} ; 3$, Lin-C7-CH $3 ; 4$, Lin- $\mathrm{C} 8-\mathrm{CH}_{3} ; 5$, Lin-C5- $\mathrm{CH}_{2} ; 6$, LinC1- $\mathrm{CH}_{2 a} ; 7$, Lin-C6-CH; , Lin-C1$\mathrm{CH}_{2 b}$; 9, Lin-C2-CH. Abbreviations: $\beta C, \beta$-Caryophyllene; Eug, Eugenol; AcEug, Eugenyl acetate; $\mathrm{Ar}$, Aromatic-H; Euc, Eucalyptol; G, Geranial; N, Neral; L, Limonene; Lin, Linalool \%"

(Figure 2). 


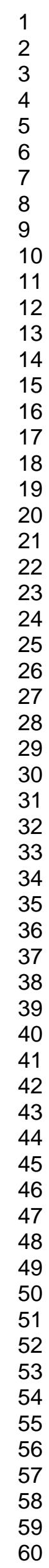

$159 \times 318 m m(96 \times 96$ DPI)

http://mc.manuscriptcentral.com/ptr 